\title{
New Aspects of Celtic Gold Coinage Production in Europe
}

\author{
HG Bachmann, A Burkhardt, R Dehn and WB Stern \\ Wildaustrasse 5, D-63457 Hanau, Germany
}

\begin{abstract}
New archaeological finds at the Celtic oppidum (site) of Tarodunum/Kirchzarten, near Freiburg (SouthGermany, Black-Forest Region) and their analytical evaluation add another chapter to the still enigmatic Celtic metallurgy, especially in relation to the production of gold/silver/copper alloys for coinage.
\end{abstract}

\section{ON CELTIC GOLD COINAGE IN GENERAL}

The first and most ancient Celtic gold coins are imitations of Greek gold staters, minted under the reign of Philipp II of Macedonia (382-336 BC). The precious metal for this coinage probably came from mines in the Pangaion Mountains (1). The average weight of these Greek gold staters was about 8.6 grams and their fineness always came close to 990 (2). The dating of these so-called Philippou staters poses problems, because even posthumous issues bear the name of Philippou (3). The Philippou staters were much appreciated among Celtic tribes. Although the very beginning of an indigenous Celtic coinage in Central Europe can be dated from finds associated with Celtic burials, ie the $3^{\text {rd }}$ century BC (4), many questions related to their introduction still remain unanswered. This is partly because early Celtic imitations of the Greek coins are rare.

Only about one hundred years later, $i e$ in the middle of the $2^{\text {nd }}$ century $\mathrm{BC}$, the minting of Celtic gold coins increased considerably (5). These later issues differ in many respects not only from the Greek originals, but also from the earlier Celtic imitations. The $2^{\text {nd }}$ century Celtic gold coinage occurs in several denominations, such as stater nominals down to fractions of quarter-staters. The new types are of significantly lower weight than the Greek prototypes: 7 grams for the stater pieces and about 1.8 grams for the quarter staters. Contrary to common opinion among numismatists, this should not be regarded as an intentional reduction in weight due to debasement. It is actually the result of maintaining the coins' volumes constant, though their fineness was reduced. Consequently, lower gold contents meant reduced weight (6). The gold content in these coins varies between 50 and $70 \mathrm{wt} \%$ (average $60 \mathrm{wt} \%$ ), with increased silver percentages of 20 to $40 \mathrm{wt} \%$ (average $33 \mathrm{wt} \%$ ) and only a residual copper content of around $10 \mathrm{wt} \%$ (average $7 \mathrm{wt} \%$ ).

Specific to Celtic gold coins originating from the Upper Rhine Valley and manufactured from alloys of the ternary system $\mathrm{Au}-\mathrm{Ag}-\mathrm{Cu}$, is an increasing silver content (7). With a gold content below 50 per cent, it is only justified to label these coins as gold staters of the Philippou type because of their iconographic and typological characteristics. At the end of this interesting monetary and numismatic development (around 100 to $80 \mathrm{BC}$ ), the former gold stater of extreme fineness had finally become a coin consisting of about 800 parts of silver and 200 parts of copper. Gold is completely absent. This was made convincingly evident by chemical analyses carried out on recent finds from Basel (8).

Celtic gold coins from Anglo-Saxon territories indicate a completely different development: Here, gold is alloyed with increasing amounts of copper. Thus, the final results are pure copper coins. In the Northern expanses of the Celtic sphere of influence, silver played a less important role as alloying constituent in local mints (9).

The regional and chronological variations associated with Celtic coinage have attracted attention from numismatists, archaeologists and scientists alike. Nearly all the metals known by the $3^{\text {rd }}$ century $B C$ were at one time or another used as coinage metals, 
mostly in the form of alloys, but frequently also in their pure state.

In the Upper Rhine Valley, the $2^{\text {nd }}$ century BC proved to be a time of significant monetary transitions. Not only was gold replaced by silver, but alloying practices and technical aspects of coin production evidently underwent changes. Disc-shaped flans were replaced by globules of appropriate alloys which, after striking, resulted in coins of convex-concave shape.

\section{THE SITE OF TARODUNUM AND ITS NUMISMATIC FINDS}

Since the beginning of the $19^{\text {th }}$ century, a large fortified area (approximately 200 hectares in size), a few kilometers to the East of the city of Freiburg/ Breisgau (Black Forest Region) was identified as the Celtic Oppidum Tarodunum (= Zarten). The name of this site was first mentioned by Claudius Ptolemaios (83-161 AD) in his 'Geographike Hyphegensis'. The modern villages of Kirchzarten and Hinterzarten still retain the roots of the original Celtic word in their names. Archaeological excavations at Tarodunum revealed a type of fortification corresponding to Caesar's murus gallicus. Immediately in front of the hill-site oppidum is situated a late Celtic settlement, covering an area of about 16 hectares, occupied from the $2^{\text {nd }}$ to the $1^{\text {st }}$ centuries BC. Abundant finds of pottery, coloured glass and more than a hundred coins of precious and base metals are proof of extensive Celtic workshop activities, particularly in the realm of metals.

Among the spectacular artifacts excavated in the relatively small workshop area of the Celtic oppidum of

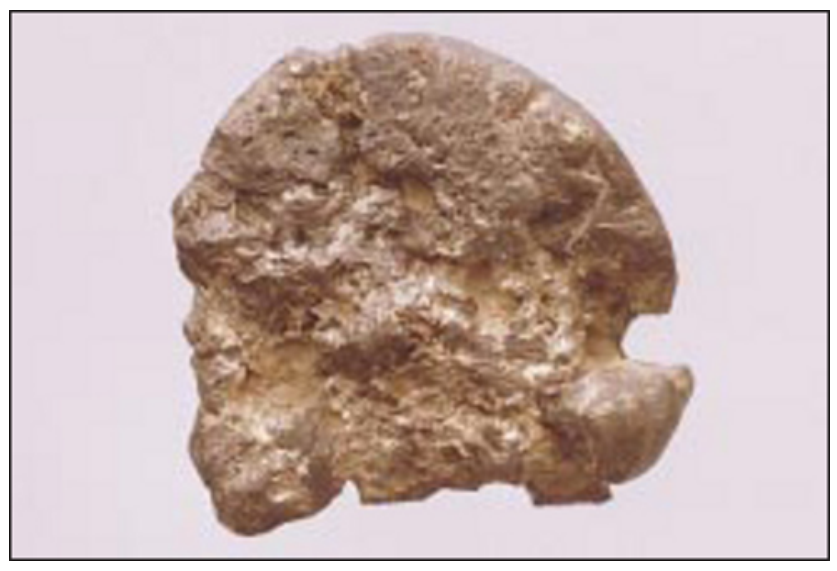

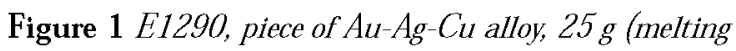
residue), magnification 3.5

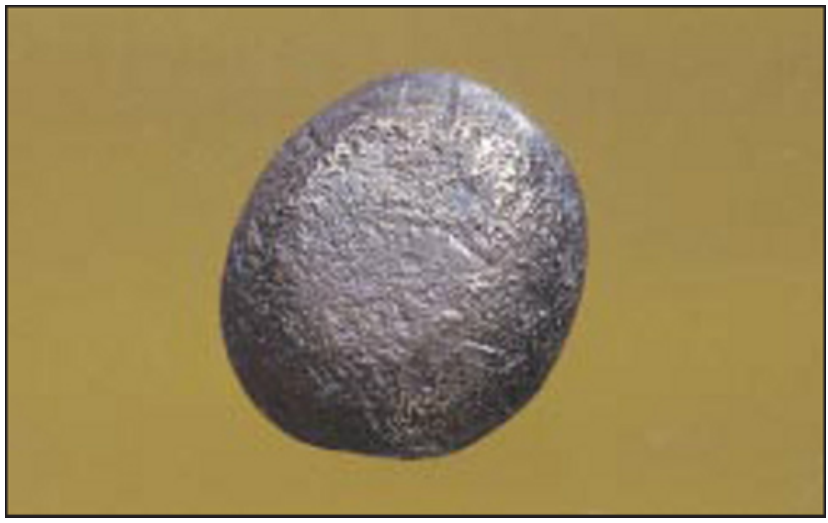

Figure 2 E1294, flan or blank prior to striking, magnification 3.5

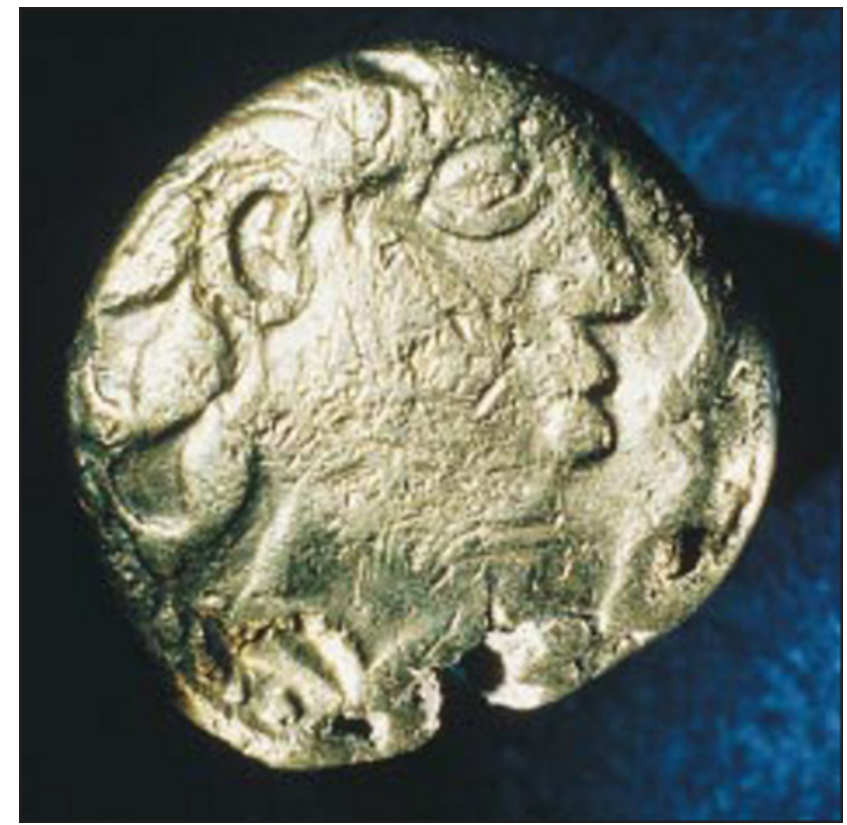

Figure 3 E1292, obverse Philippou-type, magnification 3.5

Tarodunum is an unprecedented assemblage of objects: runners of spilled metal, a flan or blank, lost prior to striking, and also a series of well preserved coins of the late Philippou type without the Greek inscriptions (10) (Figures 1-3). The brownish tarnish or surface colour of all these finds resembles that of bronze. Coins, blank and melting residues analysed by energy-dispersive XRF and TN-SPECTRACE 5000 (11), revealed the true nature of these metal objects: their average composition came close to 40 per cent of gold, 50 per cent of silver and 3 to 9 per cent of copper. Additionally, the objects in question were characterized by microprobe and/or scanning electron microscope investigations. The results are presented here for the first time, together with their metallurgical interpretation. 
Table 1 Results of XRF-Analyses Performed on Selected Areas (ca $5 \mathrm{sq}$ mm each) of Samples*

\begin{tabular}{|c|c|c|c|c|c|c|c|c|c|c|c|c|c|c|c|}
\hline Inv-No. & Object & grams & $\mathrm{g} / \mathrm{cm}^{3}$ & $\begin{array}{c}\text { EDXRF } \\
\text { wt-\% }\end{array}$ & $\begin{array}{c}\mathrm{Ag} \\
\%\end{array}$ & $\begin{array}{c}\text { Au } \\
\%\end{array}$ & $\begin{array}{c}\text { As } \\
\%\end{array}$ & $\begin{array}{l}\mathrm{Bi} \\
\%\end{array}$ & $\begin{array}{l}\mathrm{Cu} \\
\%\end{array}$ & $\begin{array}{c}\mathrm{Fe} \\
\%\end{array}$ & $\begin{array}{c}\mathrm{Hg} \\
\%\end{array}$ & $\begin{array}{c}\mathrm{Ni} \\
\%\end{array}$ & $\begin{array}{c}\mathrm{Pb} \\
\%\end{array}$ & $\begin{array}{c}\mathrm{Sb} \\
\%\end{array}$ & $\begin{array}{l}\text { Sn } \\
\%\end{array}$ \\
\hline E1293 & Philippou & 5.50 & 9.4 & $\begin{array}{l}\text { OB1 } \\
\text { OB2 }\end{array}$ & $\begin{array}{l}58 \\
58\end{array}$ & $\begin{array}{l}38 \\
37\end{array}$ & $\begin{array}{l}0.02 \\
0.02\end{array}$ & $\begin{array}{l}0.01 \\
0.02\end{array}$ & $\begin{array}{l}4.0 \\
3.8\end{array}$ & $\begin{array}{l}0.01 \\
0.12\end{array}$ & $\begin{array}{l}0.27 \\
0.15\end{array}$ & 0.01 & $\begin{array}{l}0.21 \\
0.23\end{array}$ & $\begin{array}{l}0.01 \\
0.00\end{array}$ & $\begin{array}{l}0.03 \\
0.02\end{array}$ \\
\hline F12338 & Philippou & 4.19 & 7.9 & $\begin{array}{l}\mathrm{OB} \\
\mathrm{RV}\end{array}$ & $\begin{array}{l}54 \\
52\end{array}$ & $\begin{array}{l}36 \\
43\end{array}$ & $\begin{array}{l}0.00 \\
0.03\end{array}$ & $\begin{array}{l}0.05 \\
0.00\end{array}$ & $\begin{array}{l}7.9 \\
3.6\end{array}$ & $\begin{array}{l}1.39 \\
0.12\end{array}$ & 0.27 & 0.03 & $\begin{array}{l}0.11 \\
0.23\end{array}$ & $\begin{array}{l}0.02 \\
0.02\end{array}$ & $\begin{array}{l}0.37 \\
0.16\end{array}$ \\
\hline E1292 & Philippou & 5.14 & 8.2 & $\begin{array}{l}\mathrm{OB} \\
\mathrm{RV}\end{array}$ & $\begin{array}{l}54 \\
52\end{array}$ & $\begin{array}{l}42 \\
43\end{array}$ & $\begin{array}{l}0.01 \\
0.03\end{array}$ & $\begin{array}{l}0.00 \\
0.00\end{array}$ & $\begin{array}{l}3.3 \\
3.6\end{array}$ & $\begin{array}{l}0.19 \\
0.12\end{array}$ & $\begin{array}{l}0.20 \\
0.27\end{array}$ & 0.01 & $\begin{array}{l}0.11 \\
0.23\end{array}$ & $\begin{array}{l}0.02 \\
0.02\end{array}$ & $\begin{array}{l}0.07 \\
0.16\end{array}$ \\
\hline E1294 & Blank/Flan & 4.53 & 7.4 & $\begin{array}{l}\text { S1 } \\
\text { S2 }\end{array}$ & $\begin{array}{l}52 \\
51\end{array}$ & $\begin{array}{l}42 \\
43\end{array}$ & $\begin{array}{l}0.03 \\
0.02\end{array}$ & $\begin{array}{l}0.05 \\
0.01\end{array}$ & $\begin{array}{l}3.7 \\
4.3\end{array}$ & $\begin{array}{l}0.77 \\
0.35\end{array}$ & $\begin{array}{l}0.35 \\
0.23\end{array}$ & $\begin{array}{l}0.02 \\
0.02\end{array}$ & $\begin{array}{l}0.33 \\
0.33\end{array}$ & $\begin{array}{l}0.10 \\
0.08\end{array}$ & $\begin{array}{l}0.11 \\
0.09\end{array}$ \\
\hline E1290 & Production & 25.2 & $*$ & $\begin{array}{l}\mathrm{A} 1 \\
\mathrm{~A} 2 \\
\mathrm{~A} 3 \\
\mathrm{~A} 4\end{array}$ & $\begin{array}{l}54 \\
53 \\
60 \\
55\end{array}$ & $\begin{array}{l}41 \\
37 \\
32 \\
37\end{array}$ & $\begin{array}{l}0.00 \\
0.03 \\
0.04 \\
0.01\end{array}$ & $\begin{array}{l}0.04 \\
0.03 \\
0.06 \\
0.04\end{array}$ & $\begin{array}{l}3.9 \\
6.5 \\
6.4 \\
4.7\end{array}$ & $\begin{array}{l}0.58 \\
2.25 \\
0.68 \\
1.01\end{array}$ & $\begin{array}{l}0.15 \\
0.18 \\
0.29\end{array}$ & $\begin{array}{l}0.00 \\
0.00 \\
0.06 \\
0.55\end{array}$ & $\begin{array}{l}0.19 \\
0.23 \\
0.33 \\
0.20\end{array}$ & $\begin{array}{l}0.02 \\
0.02 \\
0.07 \\
0.15\end{array}$ & $\begin{array}{l}0.00 \\
0.00 \\
0.44 \\
0.20\end{array}$ \\
\hline F9722 & Production & 14.0 & * & $\begin{array}{l}\mathrm{A} 1 \\
\mathrm{~A} 2\end{array}$ & $\begin{array}{l}45 \\
50\end{array}$ & $\begin{array}{l}51 \\
46\end{array}$ & $\begin{array}{l}0.01 \\
0.04\end{array}$ & $\begin{array}{l}0.02 \\
0.04\end{array}$ & $\begin{array}{l}3.2 \\
3.3\end{array}$ & $\begin{array}{l}0.08 \\
0.15\end{array}$ & 0.08 & $\begin{array}{l}0.02 \\
0.01\end{array}$ & $\begin{array}{l}0.22 \\
0.17\end{array}$ & $\begin{array}{l}0.04 \\
0.05\end{array}$ & $\begin{array}{l}0.04 \\
0.05\end{array}$ \\
\hline \multirow[t]{2}{*}{ F9723 } & Production & 3.16 & * & $\begin{array}{l}\mathrm{A} 1 \\
\mathrm{~A} 2\end{array}$ & $\begin{array}{l}49 \\
48\end{array}$ & $\begin{array}{l}40 \\
42\end{array}$ & $\begin{array}{l}0.03 \\
0.01\end{array}$ & $\begin{array}{l}0.11 \\
0.06\end{array}$ & $\begin{array}{l}8.8 \\
9.3\end{array}$ & $\begin{array}{l}0.86 \\
0.21\end{array}$ & 0.09 & $\begin{array}{l}0.63 \\
0.68\end{array}$ & $\begin{array}{l}0.08 \\
0.05\end{array}$ & $\begin{array}{l}0.25 \\
0.15\end{array}$ & 0.07 \\
\hline & & & & $\begin{array}{l}\text { AVG } \\
\text { STD }\end{array}$ & $\begin{array}{l}53.3 \\
4.13\end{array}$ & $\begin{array}{l}40.0 \\
4.70\end{array}$ & $\begin{array}{l}0.019 \\
0.011\end{array}$ & $\begin{array}{l}0.039 \\
0.027\end{array}$ & $\begin{array}{l}5.21 \\
2.00\end{array}$ & $\begin{array}{l}0.569 \\
0.576\end{array}$ & $\begin{array}{l}0.204 \\
0.083\end{array}$ & $\begin{array}{l}0.146 \\
0.249\end{array}$ & $\begin{array}{l}0.193 \\
0.087\end{array}$ & $\begin{array}{l}0.062 \\
0.067\end{array}$ & $\begin{array}{l}0.118 \\
0.130\end{array}$ \\
\hline
\end{tabular}

The coins belong mostly to the Philippou-type staters with their characteristic iconographic and stylistic features but without the Greek eponym, cf Sample 3 (E1292), illustrated in Figure 3. This coin's diameter is 15 to 16 millimetres, with a weight of ca 5 grams, which is already well below the usual weight of staters. Sample 2 (E1294) has survived as blank in the shape of a flat, oval piece of metal, 13 to 14 millimetres in diameter (Figure 2), while sample 1 (E1290) is a melting residue of $\mathrm{Au}-\mathrm{Ag}-\mathrm{Cu}$ alloy, weighing 25 grams, with small pieces of adhering charcoal (Figure 1).

Results of XRF-analyses (simultaneous ED-XRF of 20 elements with ordering numbers 11 to 92 in the Periodic Table) performed on selected areas (about 5 square millimetres each) of these samples are summarized in Table 1.

$\mathrm{Cd}, \mathrm{Co}, \mathrm{Cr}, \mathrm{Mn}, \mathrm{Ni}, \mathrm{P}, \mathrm{Pd}, \mathrm{Pt}, \mathrm{S}, \mathrm{Te}, \mathrm{Zn}$ are absent, at least within the limits of detection (below 0.001 to $0.01 \mathrm{wt} \%$ ). Only the inhomogeneous sample E1290 has a significant nickel content of up to $0.5 \%$ - see below.

The similarity in chemical composition of all the finds analysed (coins, blank, production residues) is remarkable - see 'Average contents of elements and standard deviations' (bottom lines on Table 1). The variable iron contents are probably due to soil contamination and/or - as for instance in sample E1290 - to slag inclusions.

However, contrary to other Celtic sites from which coin production is known, eg Manching, near Ingolstadt in Bavaria, no coin moulds were discovered among the many pottery sherds at Tarodunum (12). Thus, it is not devious to propose an alternative mode of manufacturing blanks, ie melting the proportional mixture of starting materials (pure metals, scrap, master alloys etc.) in crucibles. The liquid coin metal would subsequently be cast into temporary moulds to make spherical blanks. Under the SEM the surviving blank shows a porous surface (Figure 5), while the surface of a coin is relatively dense and smooth (Figure 4), due to the impact of the striking blow. The blank could have been cleaned prior to striking by 'pickling' in organic acids. Such a process would partly dissolve base metals or oxides from the surface of the ternary

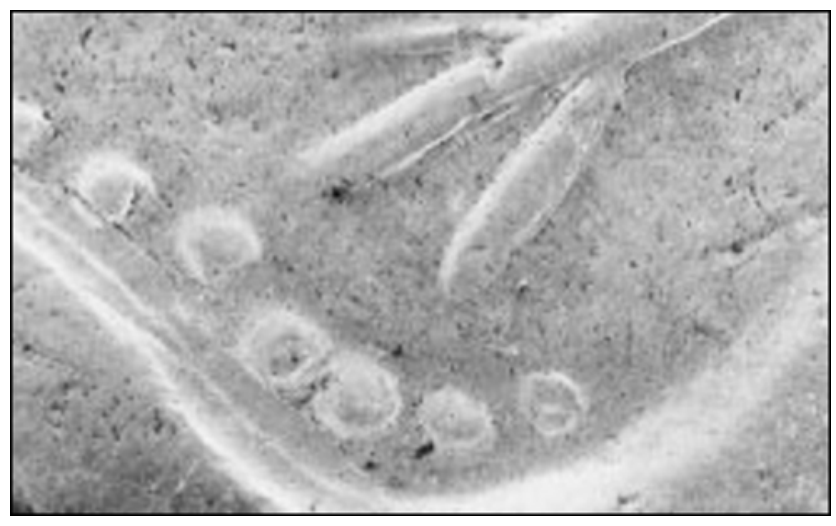

Figure 4 E1292, SEM, reverse of the Philippou-imitation, magnification 40 


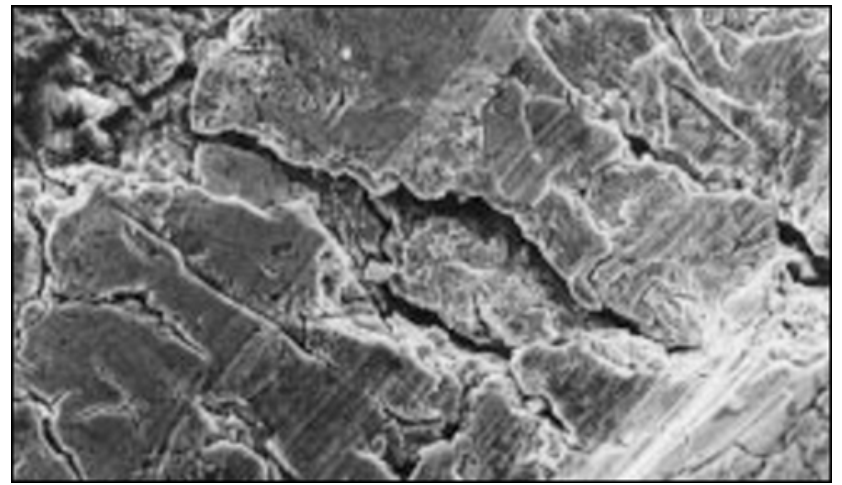

Figure 5 E1294, SEM of the porous flan/blank, magnification 1,000

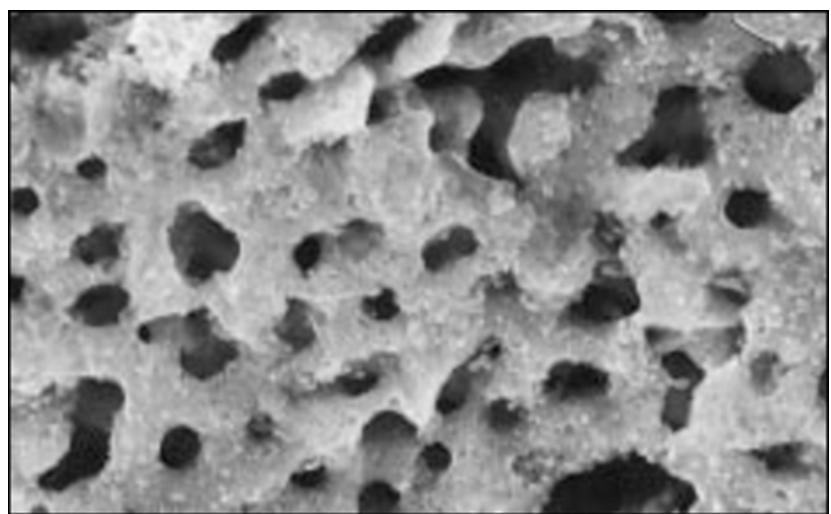

Figure 6 F9722, SEM of channels and holes, magnification 1,000

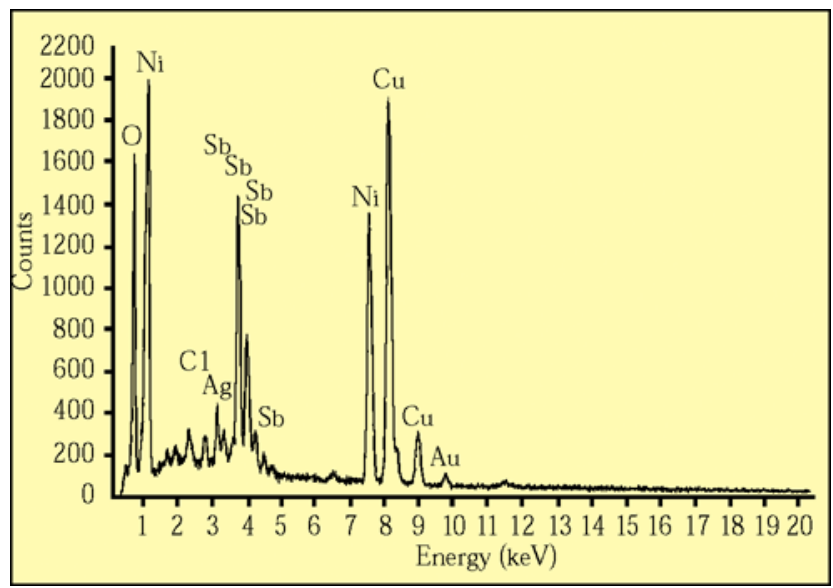

Figure 7 F9723, SEM qualitative analysis using Philips (TRACOR) instrument

alloy. This surface depletion of base metals and enrichment of noble metals was already common practice in early mints. However, we have no proof that in the case of Tarodunum finds this technique was applied to claim a higher gold fineness for the coin than actually corresponds to the alloy matrix. The colours of coins and blank are alike as are the compositions. A pronounced intentional surface enrichment would have shown immediately in the results of the ED-XRF analyses with their lower power of penetration.

The change in density from blank to coin becomes obvious when comparing calculated with measured densities (13). The mandatory request to restrict the investigations to non-destructive methods, prohibited the preparation of polished sections for metallographic examinations. Only micrographs would have revealed whether cold or hot striking was practised at Tarodunum.

Scanning electron microscopy (SEM) (14), combined with quantitative XRF-surface analyses, was employed to investigate two additional metallic finds from the same site: Samples F9722 (14 grams) and F 9723 (ca 3 grams). According to their composition, these specimens were also part of the mint's metallic relics. They too belong to the ternary system Au-Ag$\mathrm{Cu}$ with an average ratio of these main elements of $\mathrm{Ag}: \mathrm{Au}: \mathrm{Cu}=5: 4: 1$.

Analyses of the cavernous, porous surface of sample F9722 gave chlorine (3 to 8 per cent) as additional main constituent. The presence of chlorides in this material is thus obvious. Under high magnification, the specimen's surface (Figure 6) shows an interesting, strikingly regular pattern of channels and holes, explaining the porosity mentioned.

The smaller metallic fragment F9723 is very similar in composition to F9722, with gold, silver, copper and chlorine present and with the same spongy, porous channel-perforated surface. However, in selected areas of this sample antimony, nickel and copper are surprisingly the dominating elements (Figure 7). These areas are hexagonal mica-like platelets (Figure 8), completely different in their morphology from the porous matrix. The mean values of several

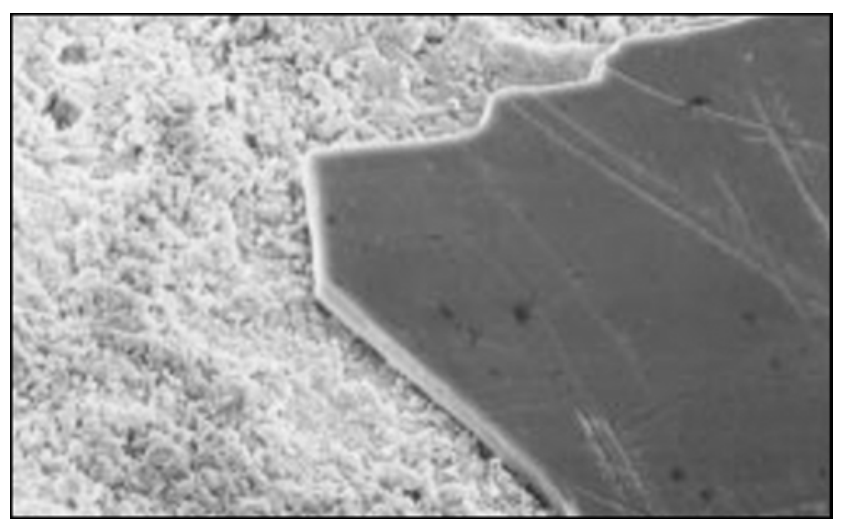

Figure 8 F9723, SEM of one mica platelet ( $\mathrm{Cu}-\mathrm{Ni}$-Sb), magnification 100 
Table 2 Mean values of point analyses on the mica-like platelets on Sample F9723, shown in Figure 8

$\begin{array}{cccc}\text { Element } & \text { wt\% } & \text { at\% } & \begin{array}{r}\text { Ratio with reference } \\ \text { to } \mathrm{Sb}=1\end{array} \\ \mathrm{Sb} & 23.223 & 8.165 & 1.00 \\ \mathrm{Ni} & 21.200 & 15.457 & 1.89 \\ \mathrm{Cu} & 36.123 & 24.336 & 2.98 \\ \mathrm{O} & 19.452 & 52.041 & 6.37\end{array}$

point analyses on these crystals are given in Table 2 . These values correspond to a substance of the following formula $\mathrm{Cu}_{3} \mathrm{Ni}_{1.9} \mathrm{SbO}_{6.4}$.

This is reasonably close to the composition of a compound known among extractive metallurgists as 'Kupferglimmer' (copper mica). It was (and still is) observed occasionally in copper metal. 'Kupferglimmer' is stable even during the most rigorous refining processes, like poling, and cannot be removed by oxidation (15). The most recent and detailed characterization of this mixed oxide was published by Chen and Dutriac (16). These authors give $\mathrm{Cu}_{3} \mathrm{Ni}_{2-x} \mathrm{SbO}_{6-x}$ (with $\mathrm{x}=0.1$ to 0.2 ) as the composition range for 'Kupferglimmer'.

Partial substitution of copper by nickel (and vice versa) is possible, but the antimony level always remains constant. There is no doubt that the complex Celtic metal prill contains exactly this compound as hard to remove impurity, probably introduced in the course of the extraction of copper from local polymetallic ores containing $\mathrm{Sb}$ and $\mathrm{Ni}$ (17).

\section{CONCLUSIONS}

Finds from excavations of the Celtic site at Tarodunum near Freiburg have been investigated by non-destructive methods (XRF, microprobe, SEM). The results are interpreted as one more contribution towards understanding Celtic coin production methods. The various steps from metal to coin are represented by coins, a corresponding blank and melting residues apparently all from the same ternary gold/silver/copper alloy with a ratio of $\mathrm{Au}: \mathrm{Ag}: \mathrm{Cu}=40: 55: 5$. In the course of these investigations an interesting metallurgical detail was discovered ie the inclusion of crystals of coppermica, a complex oxide of copper, nickel and antimony. The results presented here anticipate the final excavation report, still in preparation. They add to our knowledge in understanding minting techniques at the Celtic site of Tarodunum during the $2^{\text {nd }}$ century BC, a settlement situated in a region which was rich in mineral deposits and had abundant occurrences of placer gold in the river Rhine; ideal prerequisites for metal and alloy production.

\section{ABOUT THE AUTHORS}

Prof Dr Hans-Gert Bachmann studied chemistry, mineralogy and geology. He became involved in archaeometallurgical research in the mid-fifties. Until his retirement he was senior research scientist with Degussa. He held teaching appointments at the Institute of Archaeology, University College London, and at the University of Frankfurt/Main (Germany).

Dr Andreas Burkhardt studied archeology, human anthropology and history at the universities of Münster and Freiburg (Germany) and Basel (Switzerland). For over ten years he has carried out interdisciplinary work in the Geochemical Laboratory (Department of Earth Sciences) and in the Institute for Prehistoric Archaeology (both Basel University, Switzerland). He now runs his own company, the 'Institute for Non-Destructive Analysis and Archaeometry' in Bern, Switzerland.

Dr Rolf Dehn is head conservator of the Archaeological Department, Landesdenkmalamt Freiburg/Breisgau (Black-Forest). He has been responsible for all archaeological finds and excavations since 1977.

Prof Dr Willem B Stern, a mineralogist by training, is head of the Geochemical Laboratory (Department of Earth Sciences, Basel University). He is a specialist in non-destructive material characterization and forensic analyses of antique and modern artefacts.

\section{REFERENCES}

1 See Didor 16, 8, 5-7; Herodot 7, 112.9, 75; Euripides, Rhesos, 921-922; Xenophon, Hellenika 5, 2, 17; Strabo 7, 33.34.36; Plinius, Natural History 7, 197 and G. Le Rider in 'The Coinage of Philip and the Pangaion Mines' (in: M.B.Hatzopoulos, L.D.Loukopoulos (Eds) 'Philip of Macedon', Athens 1980, pp. 48-49 and for detailed discussion D.Keller in 'Gedanken zur Datierung und Verwendung der Statere Philipps II und ihrer Keltischen Imitationen, Schweizerische Numismatische Rundschau', 1996, $75,101-120$.

2 Results of ten unpublished ED-XRF analysis of Philippou-staters in private collections Geochemical Laboratory MPI, Basel University); the fineness comes close to Au 990 with the additional $\mathrm{Cu}$ and $\mathrm{Ag}$ contents adding up to $\mathrm{ca} 1 \mathrm{wt} \%$, which means refined gold has been struck

3 For detailed discussion of this particular problem see G. Le Rider, 'Le Monnayage d'Argent et d'Or de Philippe II Frappé en Macedoine de 359 à 294', Paris 1977 and 
M.Price, 'The Coinage in the Name of Alexander the Great and Philip Arrhidaeus', A British Museum Catalogue (The Swiss Numismatic Society in association with the British Museum Press), Zürich/London 1991 (2 volumes, 637pp, 159 plates).

4 For archaeological dating of Celtic coins found in burials see H.Polenz, Münzen in Latènezeitlichen Gräbern Mitteleuropas aus der Zeit Zwischen 300 und 50 v.Chr. Bayerische Vorgeschichtsblätter' 1982, 47, 27-222.

5 D.F. Allen, 'The Philippus in Switzerland and the Rhineland, Schweizerische Numismatische Rundschau', 1974, 53, 42-74; H.Polenz - op cit(4). One Philippou type called the 'Quarter Stater of Horgen-Unterentfelden' is very common in Switzerland (see K. Castelin, "Keltische Münzen. Katalog der Sammlung des Schweizerischen Landesmuseums Zürich, Stäfa',1978, coins No 878 to 903 and 921 to 933) and is well dated to the first part of the second century $\mathrm{BC}$.

6 First verified by A. Burkhardt, WB. Stern, G. Helmig, "Keltische Münzen aus Basel. Numismatische und metallanalytische Untersuchungen [KMBS]', Antiqua 25, Basel 1994 (434pp, 300 figures) see pp. 86-88, Figure 87, p.117 and W.B.Stern, 'On NonDestructive Analysis of Gold Objects' in 'Prehistoric Gold in Europe. Mines, Metallurgy and Manufacture' (Eds. G. Morteani, J.P. Northover, NATO ASI Series), Applied Sciences, 1995, 280, 317-328 - contrary to common numismatic opinion (R.D. van Arsdell, 'Celtic Coinage of Britain', London 1989).

7 A. Burkhardt, W.B. Stern, G. Helmig, KMBS 1994 (op cit(6)) and A. Burkhardt, R. Dehn, H.G. Bachmann and W.B. Stern, 'Keltische Münzen aus latènezeitlichen Siedlungen des Breisgau in 'Numismatische und Archäometallurgische Untersuchungen' to be published - this monograph will also give the complete record of the archeological excavation and details of the finds.

8 See (7) and for a numismatic-analytical synopsis of all coin finds of the $U_{p p e r}$ Rhine Valley see A. Burkhardt, 'Quantitative Methoden zur Keltischen Numismatik am Beispiel der Münzfunde aus Latènezeitlichen Siedlungen der Oberrheinregion', Verlag Paul Haupt, Bern, 1998 (108pp, 59 figures).

9 See R.D. van Arsdell, 1986 (op.cit.(6)) and R.D. van Arsdell, "Take out the Gold but Keep the Colour, Numismatic Circular (Spink), 1989, 97, 83f and J.P. Northover,
'Materials Issues in the Celtic Coinage', BAR 222, 'Celtic Coinage: Britain and Beyond' (The Eleventh Oxford Symposium on Coinage and Monetary History, Ed. M.Mays), Oxford 1992, pp.235-300

10 Cat.-No 1-5 in A. Burkhardt, R. Dehn, H.G. Bachmann and W.B. Stern (op cit (7)).

11 For details of hard- and software see W.B. Stern in KMBS 1994 (op cit (6)), p.80.

12 For a discussion of and recent research on coin moulds see R. Gebhard, G. Lehrberger, G. Morteani, Ch. J. Raub, F.E. Wagner and U. Wagner, 'Coin Moulds and Other Ceramic Materials: A Key to Celtic Precious Metal Working' in 'Prehistoric Gold in Europe' ed. G. Morteani and J.P. Northover, Kluwer Academic Publishers, Dordrecht/Boston/London, 1995, pp. 273-301.

13 See W.B. Stern in KMBS 1994, pp.86-87 and Figures 86, 87; W.B. Stern 1995 (op cit(6)) and in detail (illustrated) forthcoming in A. Burkhardt, R. Dehn, H.G. Bachmann and WB. Stern (op cit (7)).

14 For SEM a Jeol 6300 and Philips 505 were used in the REM Laboratory of Prof. Dr. R. Guggenheim (Department of Earth Sciences Basel University). Thanks are due to M. Düggelin and D. Mathys. Additional measurements were carried out by $\mathrm{H}$. Everts at the Degussa Research Centre, Hanau (Germany). His assistance is also much appreciated.

15 C.F. Rammelsberg,'Lehrbuch der Chemischen Metallurgie', Berlin, 1850, pp. 210-211; C. Schnabel, 'Handbuch der Metallhüttenkunde', Vol 1, Tables 6 and 7, Berlin 1894; V. Tafel and K. Wagermann, 'Lehrbuch der Metallhüttenkunde', Vol 1, $2^{\text {od }}$ ed., Leipzig, 1951, p. 424 .

16 T.T. Chen and J.E. Dutriac, Mineralogical characterisation of anode slimes. IV. Copper-Nickel-Antimony-Oxide 'Kupferglimmer' in 'CRR Anodes and Anode Slimes' Canadian Metallurgical Quarterly, 1989, 28 (2), 127-134.

17 G. Goldenberg, J. Otto and H. Sreuer (eds.), Archäometallurgische Untersuchungen zum Metallhüttenwesen im Schwarzwald', Sigmaringen 1996, p 18; and also A. Foellmer, A. Hoppe and R. Dehn 'Anthropogene Schwermetallanreicherungen in holozänen Auensedimenten der Möhlin', (südlicher Oberrheingraben), Geowissenschaften 15, 1997, 2, 61-66

\section{DO YOU WANT TO ADVERTISE IN THIS JOURNAL

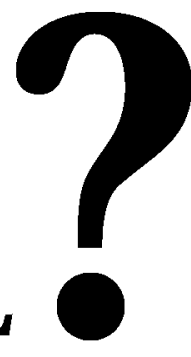

We are considering the introduction of a limited amount of advertising in Gold Bulletin. If you are interested in reaching an international audience of scientists and technologists in academia and industry with an interest in gold, this could be your opportunity.
Interested advertisers should contact the Editor, Dr C.W. Corti, World Gold Council, Kings House, 10 Haymarket, London SW1Y 4BP, England. Tel:+441719305171 - Fax: +441718396561 E-mail: chris.corti@wgclon.gold.org 